\title{
BEVEZETÉS A KÉPZŐMÜVÉSZETI ALKOTÁS KREATÍV IMITÁCIÓJÁNAK MÓDSZERTANÁBA
}

\section{Bakos Tamás}

Eötvös Loránd Tudományegyetem, Tanító- és Óvóképző Kar

Feladatunk, hogy a müalkotások érlelt nyelvi világában megjelenő sürített jelentések kreatív tevékenységekben tudatosuljanak és vezessenek személyes képi megnyilvánulásokban mutatkozó esztétikai értékítéletekhez.

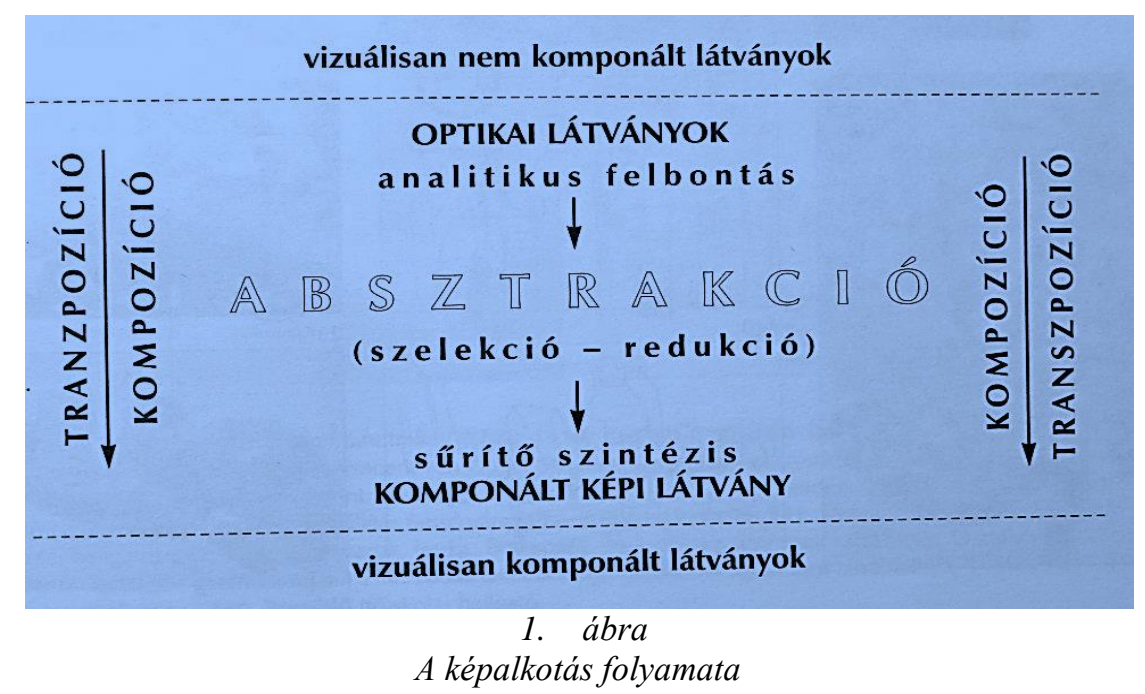

Fenti ábránk a képalkotás általános műveleti folyamatának szerkezetét szemlélteti. Hozzá kell tennünk, az optikai látvány élménytartalmával inspirálja azt a folyamatot, amely célirányos redukciók, szelekciók révén válik absztrahált egyéni szemléletü objektivizációvá, vagyis transzponált képpé. Mindez általánosságban igaz a látványalapú közvetlen tanulmányokra és a belső képekre támaszkodó szubjektív kifejező képalakításokra is. Ez utóbbi a megszürt optikai látványokra, emlékképekre, képzetekre építö, ez által személyességgel erőteljesen telített képalakítás (Bálványos, 2000; Bálványos és Sánta, 2000). Imitációról vagyis utánzásról, a közfelfogás szerint leginkább az előbbi esetben beszélünk, vagyis a modell célirányosan vizsgált tulajdonságait formáljuk képpé, amely persze már egy újfajta valóságot is jelent, hiszen a kép más jellegü nyelvi minőségben beszél, mint az optikai jelenség. Valóságnak vagy igazságtartalmú jelenségnek, jól müködő képi konvenciói miatt fogadjuk el (Hiszen ez olyan mintha élne! Mennyire hasonlít!). A modell utáni rajz - az imitáció szubjektivizmusa, a rajzoló egyéni szemlélete azonban mindig átüt a nyelvi elemek minőségével. A közvélekedés szerint nem illetjük imitáció megnevezéssel a belső képek, képzetek, emlékképek transzpozícióját, tehát a már korábbi látványok absztrakcióit.

A képalkotás pillanatában az optikai látvány már nincs jelen (Arnheim, 1978). Az alkotó személyisége kifejező célzatú vizuális nyelvi átírások segítségével, szemléleti erővel jelenik meg. Nem imitál, nem utánoz, hacsak inspirációk hiányában nem tekint vissza és merít saját korábbi képi 
objektivizációiból vagy ismétel megrendelésszerüen. Alapvetően el is érkeztünk rövid tanulmányunk kérdéseihez.

Mi történik, ha egy képalkotó más képi kifejezését imitálja? Inspirálónak tekinthető egy ilyen tevékenység és vannak e kreatív mozzanatai? Érdemes e beépíteni ilyesmit a vizuális nevelöi folyamatba? Adott kifejezési módban megfogalmazott képi alkotások imitálása. Mi ez, ha nem a képhamisító gondos munkája? Az imitációnak ez a módja, bár óriási nyelvi tudást, technikai ismeretet, jártasságokat kíván, a személyes látásmód az alkotás folyamatában teljesen háttérbe húzódik, nemkívánatos tényező. Az alkotói stílusokkal megfogalmazódó szemléletek sajátos formai megnyilvánulásai, kreatív hozzáállással is lehetnek tanulmányozás (imitálás?) tárgyai. Olyan tanulási folyamat tárgyai, amely az egyszerü szemlélésen túl, alkotói eszközökkel segíti a megcélzott kifejezés értését, átélését, és ami talán a leglényegesebb, annak alakítását.

De vessünk egy pillantást kreatív imitációnk tárgyára. A képi alkotás jelentését formai megnyilvánulásain keresztül kínálja. A vizuális nyelvi minőségek sajátos személyre szabott alkalmazása (a stílus) a jelentés hordozója, e kettő együttesen (forma és jelentés) alkotja a képi tartalmat. Ez a vizuális sajátosság nyújtja a szemlélő számára azt a hatást, amit élményként értékelhetünk (Bálványos, 2000). Formát látunk, de szemléletet észlelünk. A forma győz meg minket a kifejezés erejéről, fontosságáról, aktualitásáról. A forma stiláris sajátosságainak értelmezésével jutunk el lassan a képi jelentéshez. (Igen, ez azért olyan, mert arról szól...). A kifejezési mód vagy stílus, vizuális konvenciók alkotó által formált sajátos konstellációja. Olvashatóságuk vizuális konvenciók sokrétű ismeretét feltételezi (Arnheim, 1978; Berger 1978). Meglehet, olykor meghökkentő a látvány, mégis ha a használt konvenciókra irányítjuk figyelmünket, eljuthatunk a nekünk szóló jelentéshez, sőt manipulálhatjuk, magunkévá tehetjük a kép lényegét, kreatív imitációval. Vagyis stílust, kifejezési módot tanulunk, és aki stílust, vizuális nyelvi sajátosságokat tanul, az jelentést tanul, jelentést ért és formál, méghozzá az alkotás élményével. Vagyis magát az alkotó folyamatot sajátítja el az akadémikus rajztanulás előzményének mellőzésével. Amelyre most itt nincs is szükség. Következő példáink a kreatív mủalkotás imitáció egy-egy gyakorlati megvalósulását szemléltetik a teljesség igénye nélkül.

Orosz István kifejezési módja számunkra igen csak ismerős vizuális konvenció, a perspektíva alkalmazására épül. A térhatásnak ez a tökéletes ábrázolási módja önmaga parafrázisává válik képein. Az illúziókeltésnek ez az eszköze most afféle álvalóság kifejezője lesz, megcsalja szemünket, megfricskázza megszokásainkat. Vagyis a képi látvány a valóság hü imitációjával beszél el valótlanságokat. Teszi mindezt vizuális nyelvi aprólékossággal érzékeny, míves grafikai elemekkel -, amely egyébként a perspektíva aranykorában még inkább segítette a képi hitelesség elfogadását.

Orosz István képei persze többek optikai játéknál. Az egymásra épülö, egymásba tünő képi elemek csak látszólag idegenek egymástól. Talán a világot alkotó elemek végső összefüggéseiről beszélnek, a látszat mögött természetszerüen megbúvó mélyebb sejthető jelentésekről. A nézőt bátor képzettársításokra készteti, amelyeket látatlanul talán nem is vállalna fel. Ez a kifejezési mód ledönti, és új tartalommal ruházza fel azt, amit idáig szolgai valósághüségnek gondoltunk. Ez a valóságba bújtatott játékosan sejtelmes megoldás minket is vizuális játékra csábít. 
A tájat, fát formáló pozitív- negatív formajáték arc képzetet kelt, ugyanakkor lírai képzettársításokat inspirál. És inspirálhat kreatív imitációkat is, amelyekben Orosz István képei stiláris és kifejezésbeli összefüggéseivel nem mintái, csupán bátorító, játékos példái az önálló képi absztrakcióknak ${ }^{1}$.

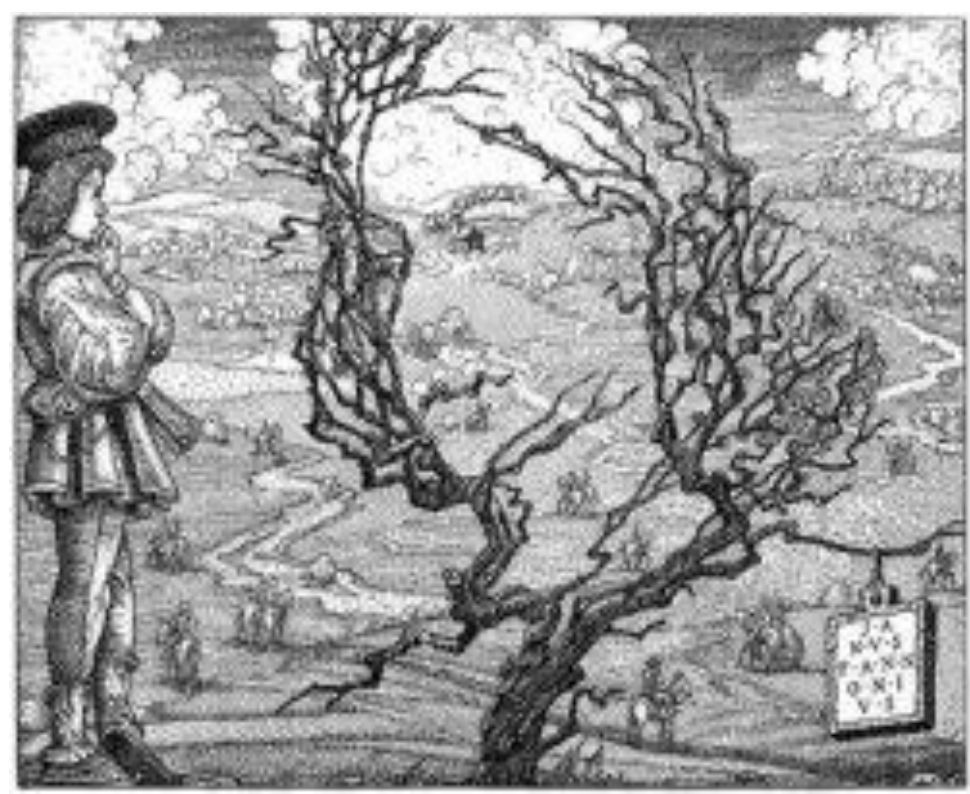

2. ábra

Orosz István: Janus Pannonius
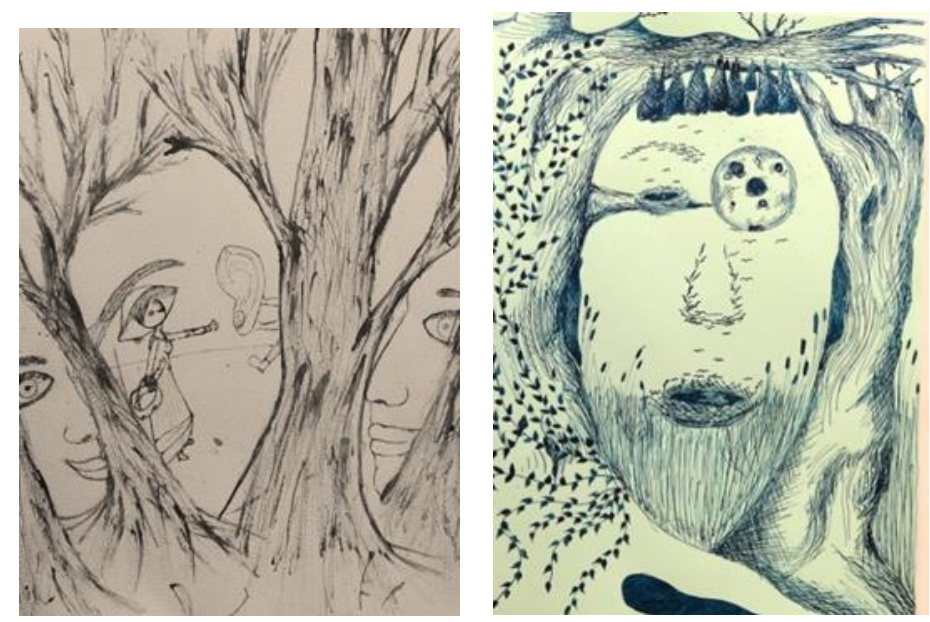

3. ábra

Az ELTE TÓK hallgatóinak munkái - oktató: Kungl György

Rékassy Csaba szintén a 20. század egyik jelentős magyar grafikusa volt. Aprólékos rajzi stílusa megfelel a tradicionális grafika nyelvi sajátosságoknak. Metszetei a düreri mesterségbeli tudás tiszteletére épülnek. Mindez tökéletesen szolgálhatná a néző valóságigényét. Rékassy viszont egy másik valóságot közvetít számunkra, amelyben a formai zsúfoltság és egy különös, felborult arányrend a jelentés egyik kulcsfontosságú közvetítő eleme. A kíméletlen rajzi aprólékosság

\footnotetext{
${ }^{1}$ http://www.artmagazin.hu/artmagazin_hirek/egy_polihisztor_perspektivai_orosz_istvan.1294.html
} 
jellemzi, amely talán arról beszél, hogy a részletek építik fel életünket, még akkor is, ha abból az abszurditás áll össze ${ }^{2}$.

Rékassy Csaba munkái a rajzi imitációban résztvevőket belső képeik mozgósítására és míves előadásmódra késztetik. A hallgatói feladat itt egy adott képrészlet folytatása az egész ismerete nélkül. Alapvetően stílusgyakorlatnak is nevezhető, amelyben képzeteink, passzív képi tárházunk közvetlen nyelvi segítséget kap.
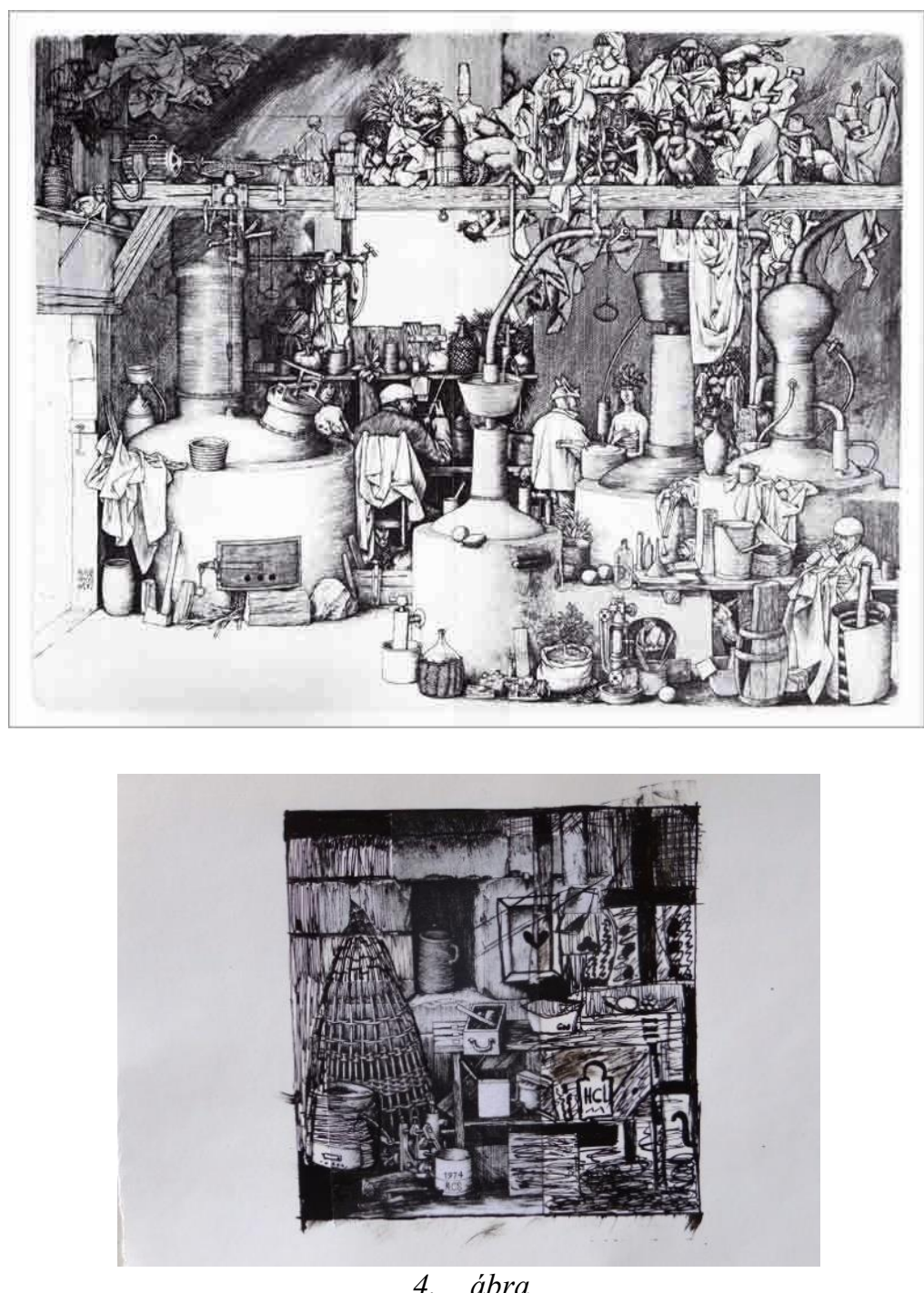

Fent: Rékassy Csaba: Pálinkafözde

Alul: Képfolytatás: hallgatói munka - oktató: Kungl György

Az elöbbieknél lényegesen szükebb formai megoldású vizuális nyelvi konvenciót alkalmaz Andy Warhol Marilyn Monroe képsorozatán. Végletes reduktivitása nem engedi a nézőt érzelmes kalandozásokra. A sokszorosítás ténye (szitanyomat), az egyediség számossá tétele pedig egyértelmüsíti, hogy a jelentés mindenkié: $M M$ a társadalmi tudat része, egyszerüen kezelhetö, funkciója van és

\footnotetext{
${ }^{2}$ http://rezkarcfitness.blogspot.hu/2011/03/rekassy-csaba.html
} 
felhasználható ${ }^{3}$. A mellékelt feladat is vizuális nyelvi átirat tárgyaként kezeli. Különböző színkontrasztok hatásainak tanulmányozásának formai kiinduló eleme. Mégis, az újraalkotás személyessége ebben a szituációban is átüt. A karakter követésének ügyetlensége, vagy éppen tudatos elhagyása, az ecsethasználat, és önmagában az újszerü személyes színhasználat is váratlan kifejezést jelenthet. Gyakran a kifejezés spontán és ráismerésszerü ebben a helyzetben.
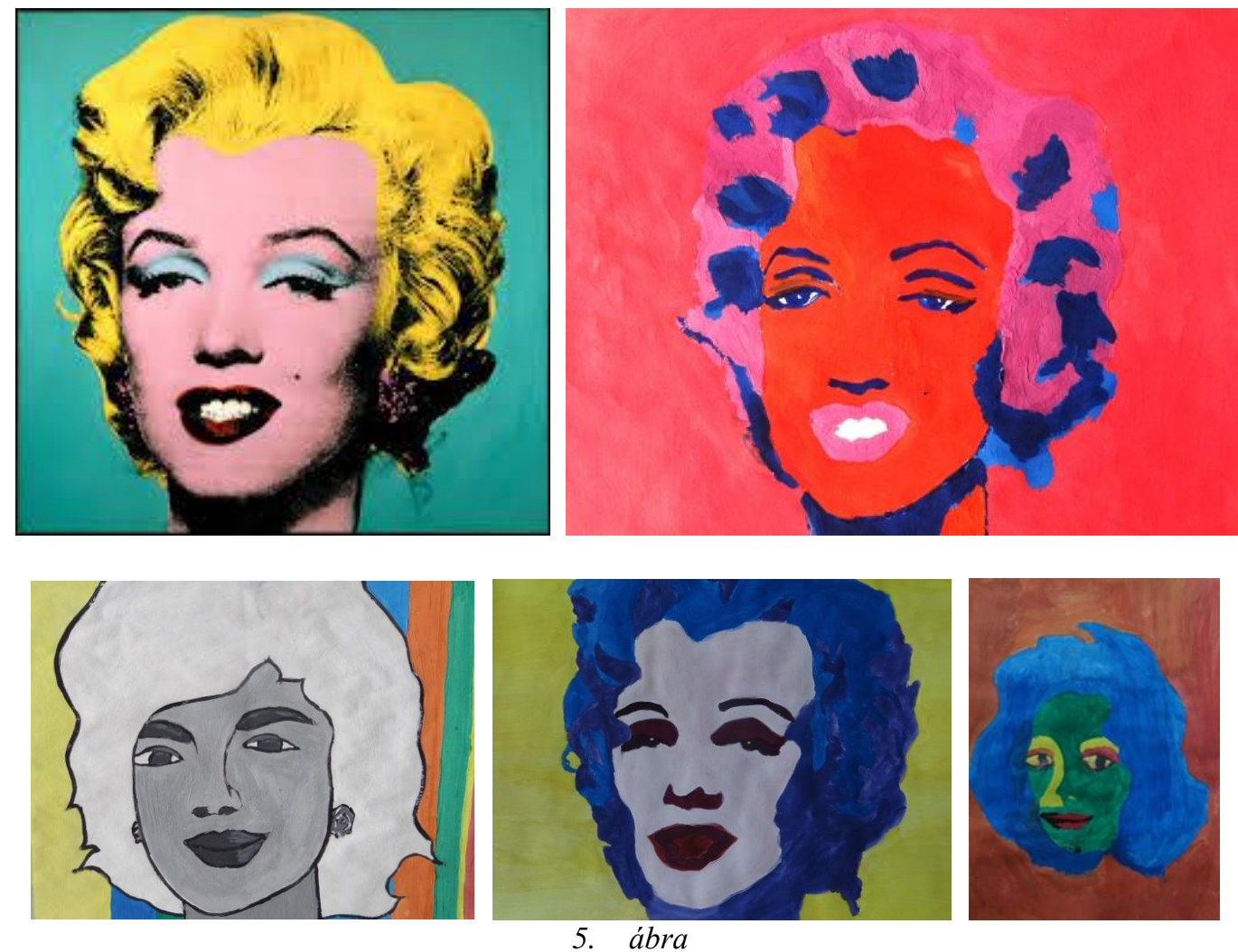

Fent: Andy Warhol: $M M$

Alul: Az ELTE TÓK hallgatóinak munkái-oktató: Bakos Tamás ${ }^{4}$

A Marilyn képek egyik tanulsága, hogy a személyes kifejezése, a kreatív átírás más lehetőségeit kínálja, ha a müalkotás közismert, esetleg föszereplője ikonná merevedett a kultúrtörténet időalagútjában. Mona Lisa az emberi kultúrának olyan kövülete, amely eredeti - mára nehezen megfejthető - jelentésén túlmutató tartalmakkal telítődött. A mellékelt képek montázsok, induló elemét alkotta Leonardo da Vinci híres festménye. Természetesen nem stiláris, leonardói kifejezési módokat felhasználó képfolytatásról van szó. A fő motívum - mint biztos jelentés - mellé keveredő képi elemek különös kapcsolatba lépnek egymással. A jelentések a klasszikus montázselv szerint egymást kioltva lépnek egy új tartalmiság dimenziójába. Mindez olyan technikával történik, amelynek gyorsasága és valóságdarabka jellege roppant inspiratív az alkotói élmény oldaláról tekintve. Nem mellékes hogy átléphetjük a rajzolás, festés tudásának nehézségeit oly módon, hogy az eredmény megjelenése meggyőző marad.

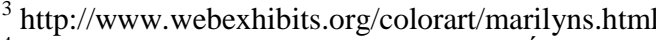

${ }^{4}$ Az egyes feladatok az ELTE Tanító- és Óvóképző Kar Alkotási gyakorlatok kurzusain valósultak meg.
} 
Alábbi képeink szemléltetik, miképpen válhat kultúránk titokzatos egyetemes szépsége korunk életérzéseit aktualizáló, közvetítő nőalakká.
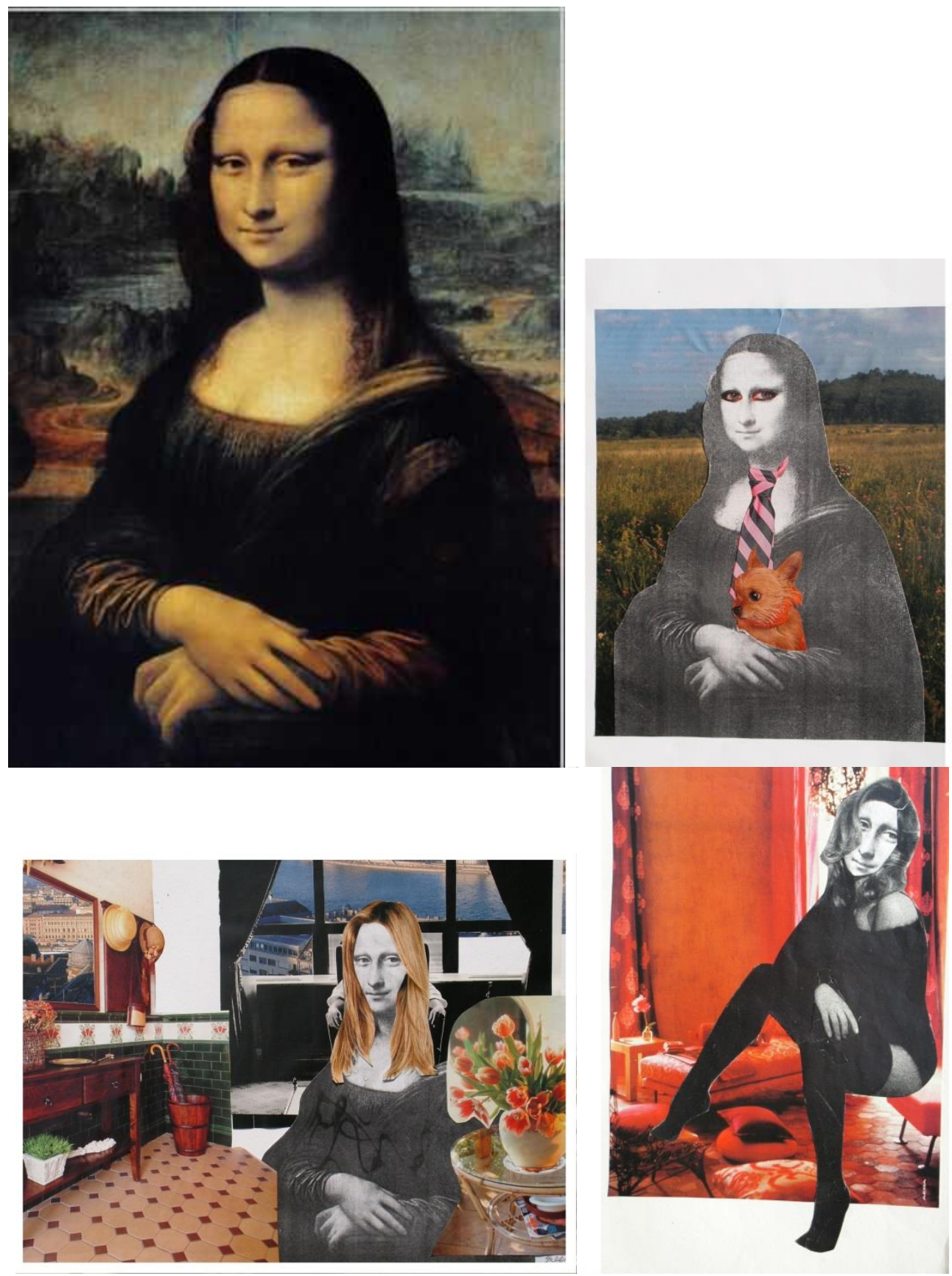

6. ábra

Balra fent: Leonardo, Mona Lisa.

Jobbra fent és alul: Az ELTE TÓK hallgatónak montázs képei - oktató: Bakos Tamás

A mindennapi oktatói gyakorlatban fellelhető és alkalmazott lehetőségek széles tárházának bemutatásra itt most nem vállalkoztunk. Elmaradnak a plasztikai alkotások imitációinak, átírásainak példái, vagy a téralakításokból adódó müfajokat egyesítő kreatív müalkotás átírások. És természetesen külön

\footnotetext{
${ }^{5}$ A tanulmányban mellékelt hallgatói munkákról készült képeket Bakos Tamás és Bálványos Huba készítette.
} 
blokkot szentelhetnénk azoknak a módszertani példáknak és lehetőségeknek, amelyek gyermekek körében mutatja meg a fenti téma változatait, létező kísérleteit.

Zárásként képies formában utalnánk Bálványos Huba (2000) Esztétikai müvészeti ismeretek, esztétikai müvészeti nevelés című munkájának záró fejezetére. A képen Ámos Imre grafikáinak felhasználásával, egy gyerekekkel folytatott kreatív müalkotás imitáció dokumentumai láthatóak.
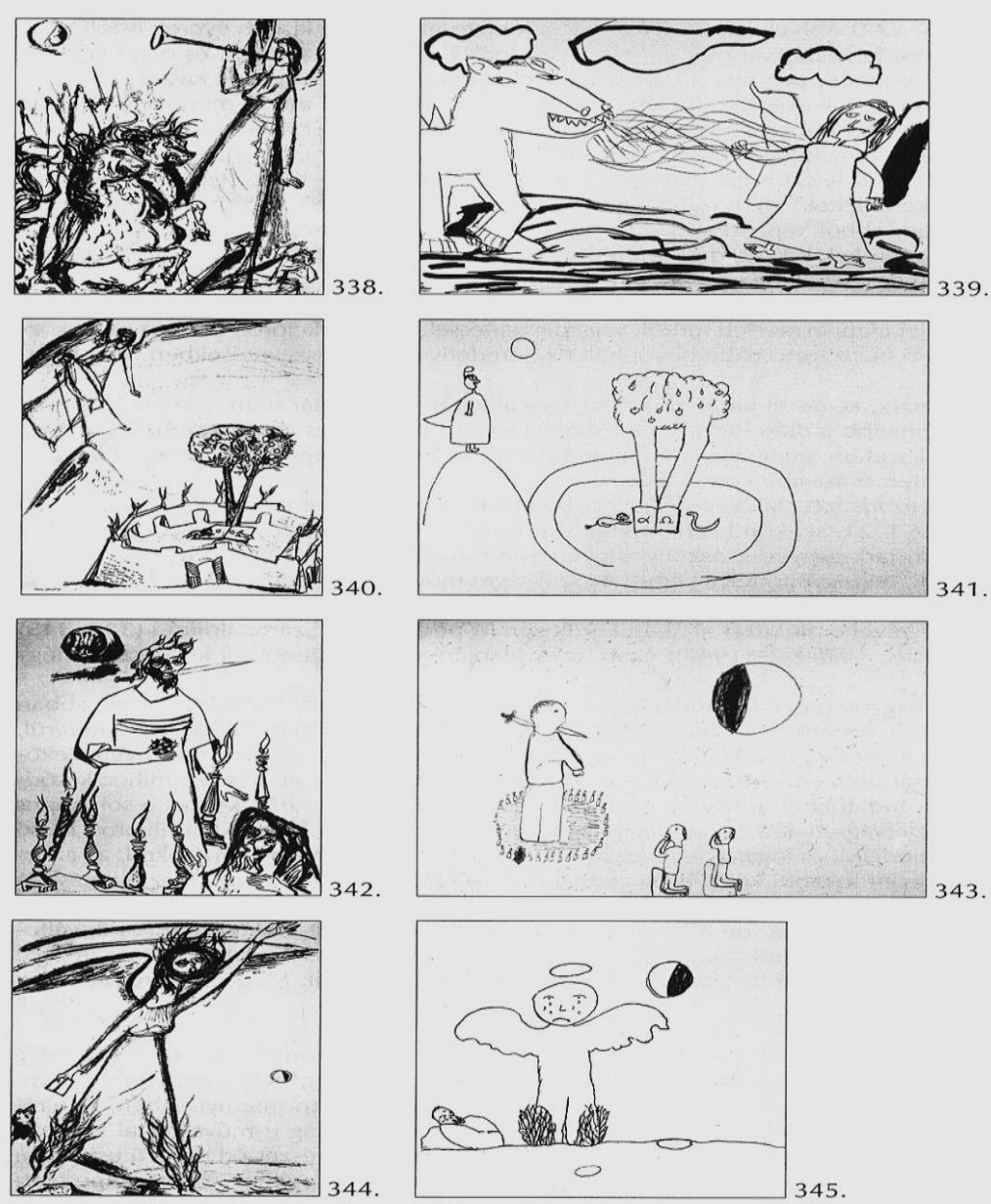

7. ábra

Baloldali oszlop: Ámos Imre grafikái

Jobb oldali oszlop: Gyermeki impressziók megjelenitése (Bálványos, 2000)

Most az olvasóra bízzuk a kérdés megválaszolását: Mi értelme lehet a kiállítás látogatást követő gyermeki impressziók rajzos megjelenítésének? 


\section{Irodalom}

Andy Warhol's Marlyn Prints. letöltés helye:

http://www.webexhibits.org/colorart/marilyns.html letöltés ideje: 2013. november 16.

Arnheim, Rudolf (1978): A vizuális élmény. Az alkotó látás pszichológiája. Gondolat Kiadó, Budapest.

Bálványos Huba és Sánta László (2000): Vizuális megismerés, vizuális kommunikáció. Balassi Kiadó, Budapest.

Bálványos Huba (2000): Esztétikai müvészeti ismeretek, esztétikai müvészeti nevelés. Balassi Kiadó, Budapest.

Berger, René (1978): A festészet felfedezése, I-II. Gondolat Kiadó, Budapest.

Kováts Gergely (2011): Egy polihisztor perspektívái. Artmagazin, 5. 16-21. letöltés helye:

http://www.artmagazin.hu/artmagazin_hirek/egy_polihisztor_perspektivai_orosz_istv an.1294.html letöltés ideje: 2013. június 5 .

Megay László (2011): A hónap alkotója: Rékassy Csaba. Rérkarcfitness, letöltés helye: http://rezkarcfitness.blogspot.hu/2011/03/rekassy-csaba.html letöltés ideje: 2013. június 6 . 